\title{
Model Penerimaan User Dalam Implementasi Sap (Systems Application And Product) Dengan Menggunakan Model UTAUT
}

\author{
Dermawan Hambara Kusuma * \\ Abriyani Puspaningsih **
}

\begin{abstract}
This study aims to analyze the SAP ERP system acceptance model using "Unified Theory of Acceptance and Usage of Technology" (UTAUT). UTAUT model identifies four factors driving acceptance as an independent variable performance expectations (performance expectancy), effort expectancy (effort expectancy), social influence (social influence) and supporting conditions (facilitating conditions). In addition to the four factors of the UTAUT model, this study adds Anxiety as independent variables. As dependent variable is a symbolic adoption that measures user acceptance and attitude in using the system (attitude toward system use) as an intervening variable between the independent variables and the dependent variable.

Based on 39 samples taken from the Islamic University of Indonesia Yogyakarta concluded that the model of acceptance of the SAP system with the case of this study, there are four factors that influence the acceptance of performance expectations, business expectations, anxiety, and attitudes shown to affect user acceptance by the SAP system. While the influence of social, managerial intervention and support conditions are not shown to affect user acceptance by the SAP system.

Keywords: SAP, Anxiety, Attitude Toward System Use, Symbolic Adoption, UTAUT
\end{abstract}

* Alumni Fakultas Ekonomi UII

** Dosen Fakultas Ekonomi UII 


\section{Pendahuluan}

Teknologi informasi telah meningkatkan efisiensi dan efektifitas dalam pelaksanaan aktivitas dalam organisasi. Kemampuan teknologi ERP dalam mengintegrasikan proses bisnis di suatu organisasi (perusahaan) menjadi daya tarik bagi pihak manajemen untuk mengadopsi ERP. SAP (Systems Application and Product) adalah salah satu jenis dari software aplikasi ERP yang memiliki banyak pengguna di dunia khususnya di Indonesia. Hampir $80 \%$ perusahaan besar di Indonesia menggunakan software SAP. Sistem informasi menjadi lebih modern dan realtime berkat implementasi SAP ke dalam sistem perusahaan.

Keberhasilan penggunaan teknologi tidak akan bisa berjalan dengan efektif dan sesuai dengan harapan jika pengelola (user) yang ada di dalam organisasi (perusahaan) tidak mampu atau tidak cekatan dalam menggunakan sistem yang telah diimplementasikan. Kesuksesan implementasi juga tergantung dari penerimaan dan penggunaan oleh individu-individu (user) tersebut. Pemahaman pihak manajemen mengenai faktor-faktor yang berpengaruh terhadap User Acceptance akan-membantu manajemen dalam menyelesaikan permasalahan dan menentukan langkah yang strategis untuk sukses dalam mengelola SAP pasca-implementasi.

Berbagai model dari penelitian terdahulu telah mengidentifikasi faktor-faktor yang mendorong penerimaan teknologi. Venkatesh, et.al (2003) me-review model-model penerimaan yang ada. Dari proses tersebut menghasilkan model UTAUT (Unified Theory of Acceptance and Usage of Technology). Model ini menjawab mengapa seseorang mengambil keputusan untuk menggunakan suatu software sistem teknologi informasi. Model ini berhubungan dengan faktor-faktor yang 
mengarahkan seseorang untuk menggunakan suatu sistem, serta kondisi lingkungan yang bagaimana yang memfasilitasi penggunaan sistem tersebut.

Penelitian ini mereplikasi dari penelitian sebelumnya yang dilakukan oleh Budiarningsih Marantika (2010). Dalam penelitian ini terdapat pembaharuan/perbedaan dari penelitian sebelumnya yaitu memasukkan satu variabel baru yaitu anxiety sebagai variabel independen yang mempengaruhi sikap dalam menggunakan sistem. Selain itu juga digunakan obyek penelitian yang berbeda yaitu penelitian dilakukan pada Universitas Islam Indonesia yang merupakan organisasi/instansi dalam bidang jasa (pendidikan) yang sudah mengimplementasikan sistem teknologi informasi SAP sejak tahun 2006.

Keberhasilan penggunaan teknologi tidak akan bisa berjalan dengan efektif dan sesuai dengan harapan jika pengelola (user) yang ada di dalam organisasi (perusahaan) tidak mampu atau tidak cekatan dalam menggunakan sistem yang telah diimplementasikan. Kesuksesan implementasi juga tergantung dari penerimaan dan penggunaan oleh individu-individu (user) tersebut. Pemahaman pihak manajemen mengenai faktor-faktor yang berpengaruh terhadap User Acceptance akan membantu manajemen-dalam menyelesaikan permasalahan dan menentukan langkah yang strategis untuk sukses dalam mengelola SAP pasca-implementasi.

Berbagai model dari penelitian terdahulu telah mengidentifikasi faktor-faktor yang mendorong penerimaan teknologi. Venkatesh, et.al (2003) me-review model-model penerimaan yang ada. Dari proses tersebut menghasilkan model UTAUT (Unified Theory of Acceptance and Usage of Technology). Model ini menjawab mengapa seseorang mengambil keputusan untuk menggunakan suatu software sistem 
teknologi informasi. Model ini berhubungan dengan faktor-faktor yang mengarahkan seseorang untuk menggunakan suatu sistem, serta kondisi lingkungan yang bagaimanayang memfasilitasi penggunaan sistem tersebut.

Penelitian ini mereplikasi dari penelitian sebelumnya yang dilakukan oleh Budiarningsih Marantika (2010). Dalam penelitian ini terdapat pembaharuan/perbedaan dari penelitian sebelumnya yaitu memasukkan satu variabel baru yaitu anxiety sebagai variabel independen yang mempengaruhi sikap dalam menggunakan sistem. Selain itu juga digunakan obyek penelitian yang berbeda yaitu penelitian dilakukan pada Universitas Islam Indonesia yang merupakan organisasi/instansi dalam bidang jasa (pendidikan) yang sudah mengimplementasikan sistem teknologi informasi SAP sejak tahun 2006.

\section{Kajian Pustaka}

\section{Enterprise Resource Planning (ERP)}

ERP (Enterprise Resource Planning) adalah suatu perangkat lunak/software dengan aplikasi yang terintegrasi dengan baik untuk digunakan secara luas dalam organisasi bisnis. ERP juga didefinisikan sêbagai software information system berbasis komputer yang dirancang uñtük mengolah suatu transaksi di dalam organisasi dan menyediakan fasilitas perencanaan, produksi, dan pelayanan konsumen yang realtime dan terintegrasi (Winarno, 2004).

Dalam ERP terdapat integrasi data antar unit yang ada dalam perusahaan. Data yang ada diusahakan saling dihubungkan satu dengan yang lain. Dengan demikian, dalam penerapannya ERP sangat memerlukan informasi rinci mengenai basis data. 


\section{Vendor-vendor ERP}

Suatu organisasi dapat memilih vendor ERP mana yang paling sesuai dengan kebutuhan dan karakter organisasinya. Berikut ini vendor ERP yang paling banyak digunakan secara internasional menurut AMR research tahun 2002: SAP AG, BAAN Company, ORACLE Corporation, Peoplesoft dan JD Edwards World Solution Company.

\section{Systems Application and Product (SAP)}

SAP (Systems Application and Product in data processing) adalah suatu software yang dikembangkan untuk mendukung suatu organisasi dalam menjalankan operasionalnya secara lebih efisien dan efektif. SAPterdiri dari sejumlah modul aplikasi yang mempunyai kemampuan mendukung semua transaksi yang perlu dilakukan suatu perusahaan dan tiap aplikasi bekerja secara berkaitan satu dengan lainnya. Semua modul SAP dapat bekerja secara terintegrasi. Modul dan aplikasi yang terdapat dalam suatu software SAP R/3 tergantung kepada versinya. SAP secara terus menerus melakukan upgrade terhadap software $\mathrm{R} / 3$ agar sesuai dengan kebutuhan perusahaan. Secara keseluruhan, SAP R/3 versi 4,6 C terbagi menjadi tiga functional area yaitu : Financial, Logistic dan Human Resources.

\section{UTAUT (Unified Theory of Acceptance and Usage of Technology)}

UTAUT merupakan salah satu teori pengadopsian teknologi Model UTAUT memformulasikan empat faktor yang memunculkan system acceptancedan usage dengan empat variabel moderat yang mempengaruhinya (Venkatesh, et.al : 2003). Faktor yang memunculkan user acceptance dari model UTAUT ini adalah :Performance expectancy, Effort expectancy, Social influence dan Facilitating conditions. 


\section{Pengembangan Hipotesis}

\section{Ekspektasi Kinerja}

Variabel ekspektasi kinerja merupakan faktor paling mempengaruhi penerimaan seseorang terhadap suatu teknologi. Pendapat ini didukung secara empiris berdasarkan hasil penelitian yang dilakukan oleh I Gusti Nyoman Sedana \& St. Wisnu Wijaya (2010) yang menjelaskan bahwa tingkat kepercayaan pada sistem akan meningkatkan performasi kerja sebagai awal munculnya sikap (attitude) yang positif.

$\mathrm{H}_{1}$ : Ekspektasi kinerja berpengaruh positif terhadap sikap dalam menggunakan system

\section{Ekspektasi Usaha}

Kemudahan dan sedikitnya usaha dalam memahami software akan menimbulkan sikap positif dalam menerima sistem dan mendorong user untuk menerima sistem SAP yang kompleks (Venkatesh et al., 2003)

Berdasarkan uraian di atas, maka akan semakin tinggi sikap user dalam penerimaan sistem akan meningkatkan penerimaan user dalam sistem tersebut.

to, $\mathrm{H}_{2}$ : Elspektasi usaha berpengaruh positif terhadap sikap dalam 3. Pengaruh Sosial penggunaan sistem

Faktor sosial akan mempengaruhi behavior seseorang, terdapat dalam tiga proses yaitu: 1.). Compliance .2.) Identification 3.) Internalization. Persepsi ini didukung oleh hasil penelitian yang dilakukan oleh I Gusti Nyoman Sedana \& St. Wisnu Wijaya (2010) yang menyimpulkan bahwa lingkungan di dalam suatu organisasi mempengaruhi niat mereka dalam menggunakan sistem. 
$\mathrm{H}_{3}$ : Pengaruh sosial berpengaruh positif terhadap sikap dalam menggunakan system

\section{Intervensi Manajerial}

Komitmen dan dukungan manajemen puncak merupakan bentuk dari managerial interventions. Implementasi ERP memaksa perubahan dalam organisasi baik itu struktur maupun operasional harian. Persepsi ini didukung oleh hasil penelitian yang dilakukan oleh Komara, Acep (2005) yang menjelaskan bahwa dukungan top manager (manager invention) mempengaruhi kinerja sistem informasi akuntansi. Berdasarkan uraian di atas, penelitian ini mengajukan hipotesis sebagai berikut:

$\mathrm{H}_{4}$ : Intervensi manajerial berpengaruh positif terhadap sikap dalam penggunaan system.

\section{Anxiety}

Anxiety merupakan kecenderungan seseorang menjadi susah, khawatir, cemas, atau ketakutan mengenai penggunaan teknologi informasi. Semakin cemas user terhadap inovasi teknologi akan mengakibatkan penghindaran atau penolakan user dalam menerima sistem ERP SAP. Persepsi ini didukung oleh Abdulwahab (2010) menjelaskan bahwa Anxiety tidak memiliki hubungan yang positif terhadap sikap dalam menggunakan sistem (behavior intention). Marchewka (2007) dalam penelitiannya menghasilkan kesimpulan bahwa Anxiety memiliki hubungan yang tidak positif (negative) dengan sikap dalam menggunakan sistem (behavior intention). Berdasarkan uraian di atas, dalam penelitian ini diajukan hipotesis berikut :

$\mathrm{H}_{5}:$ Anxiety berpengaruh negatif terhadap sikap dalam penggunaan system. 


\section{Kondisi Pendukung}

Faktor-faktor lingkungan yang diobservasi disetujui sebagai hal yang memudahkan sesuatu untuk dilakukan (Venkatesh, et.al (2003). Berdasarkan uraian di atas, dalam penelitian ini diajukan hipotesis :

$\mathrm{H}_{6}$ : Kondisi pendukung berpengaruh positif terhadap symbolic adoption.

\section{Sikap Dalam Menggunakan Sistem}

Attitude toward system use merupakan sikap user yang berasal dari pengaruh dalam diri user maupun pengaruh sosial terhadap penggunaan sistem ERP sebelum akhirnya memutuskan menerima sistem. Berdasarkan uraian di atas, dalam penelitian ini diajukan hipotesis berikut :

$\mathrm{H}_{7}$ : Sikap dalam menggunakan sistem berpengaruh positif terhadap symbolic adoption.

\section{Model Penelitian}

Model yang digunakan dalam penelitian ini adalah sebagai berikut :

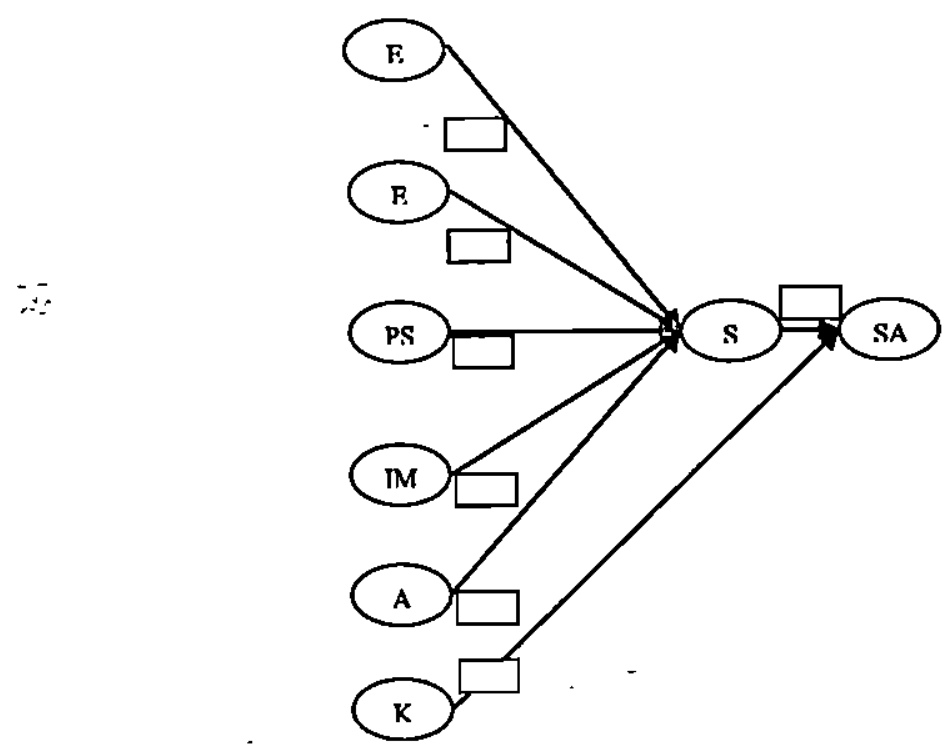




\section{Keterangan :}

EK: Ekspektasi Kinerja, DMS: Sikap Dalam Menggunakan Sistem, EU : Ekspektasi Usaha , SA: Symbolic Adoption, PS: Pengaruh Sosial, IM: Intervensi Manajerial, AX: axiety, KP: Kondisi Pendukung

\section{Metode Penelitian}

\section{Populasi dan sampel}

Populasi pada penelitian ini adalah karyawan yang menggunakan sistem informasi SAP di Universitas Islam Indonesia. Sampel dalam penelitian ini adalah pihak-pihak yang terlibat dalam penggunaan sistem informasi SAP dalam keseharian aktivitas kerjanya, yaitu karyawan yang bekerja pada bagian umum dan bagian finansial yang mewakili setiap fakultas di Universitas Islam Indonesia.

\section{Metode Pengumpulan Data}

Metode pengumpulan data yang dilakukan dalam penelitian ini adalah dengan metode angket atau kuesioner. Data diambil dengan menyebarkan kuesioner atau angket kepada orang yang memenuhi kriteria yang ditetapkan yaitu pihak-pihak yang menggunakan sistem informasi SAP dalam aktivitas kerjanya.

\section{Variabel Penelitian dan Pengukuran Variabel}

Untuk mendapatkan data yang bernilai interval, responden diminta untuk mengisi tanda ceklist di kolom berisi pilihan 1-6. Tanda ceklist yang diberikan merupakan respon yang paling sesuai dengan persepsi yang responden rasakan untuk setiap pernyataan yang diajukan. Nilai 1-6 menunjukkan tingkat persetujuan responden terhadap pernyataan.

Nilai 1 berkolerasi dengan pernyataan "sangat tidak setuju", nilai yang semakin mendekati nilai ini menunjukkan tingkat persetujuan 
responden terhadap pernyataan kuesioner rendah. Nilai 6 berkorelasi dengan pernyataan "sangat setuju", nilai yang semakin mendekati nilai ini menunjukkan tingkat persetujuan responden terhadap pernyataan kuesioner tinggi.

Dalam penelitian ini terdapat 8 variabel yaitu symbolic adoption, sikap dalam menggunakan sistem (attitude toward system use), ekspektasi kinerja (performance expectancy), ekspektasi usaha (effort expectancy), Pengaruh sosial (social influence), intervensi manajerial (managerial intervention), anxiety, dankondisi pendukung (facilitating conditions).

a. Symbolic Adoption mengacu pada mental acceptance seseorang terhadap suatu inovasi (Nah, Tan, The, 2004) yang terdiri dari 3 item. Persepsi responden terhadap indikator tersebut diukur dengan skala Likert 1-6.

b. Sikap Dalam Menggunakan Sistem diartikan sebagai suatu kecenderungan untuk tidak atau menyukai komputer sistem, aplikasi, staffing sistem atau proses yang berhubungan dengan pemanfaatan aplikasi sistem (Nah, et.al.,2004). Indikator yang digunakan berjumlah 4 item. Persepsi responden terhadap $\because$ indikator tersebut diukur dengan skala Likert 1-6 (Nah,et.al.,2004 dan Venkatesh, et.al., 2003).

c. Ekspektasi Kinerja yaitu tingkatan keyakinan user bahwa dengan menggunakan sistem akan membantu mereka menghasilkan prestasi kinerja yang maksimal. Variabel ini menggambarkan ekspektasi kinerja yang dipersepsikan oleh user yang diukur dengan skala Likert 1-6 (Venkatesh, et.al.,2003).

d. Ekspektasi Usaha didefinisikan sebagai tingkatan kemudahan yang dirasakan user dalam menggunakan sistem (Venkatesh, 
et.al., 2003). Variabel ini diukur dengan 6 item pernyataan dengan skala Likert 1-6.

e. Pengaruh Sosial yaitu kesadaran seseorang mengenai adanya pengaruh orang lain yang menggunakan sistem (Venkatesh, et.al., 2003). Variabel ini diukur dengan menggunakan 6 item pernyataan berdasarkan penelitian Venkatesh (2003) dengan skala Likert 1-6.

f. Intervensi Manajerial adalah tindakan-tindakan spesifik manajemen dan peraturan-peraturan yang dilakukan organisasi untuk mempengaruhi penerimaan ERP oleh user. Variabel ini diukur dengan 5 item pernyataan, dengan skala Likert 1-6.

g. Anxiety adalah suatu gambaran kecemasan atau reaksi secara emosi ketika dihadapkan pada atau dalam menggunakan suatu teknologi (penggunaan sistem), atau hanya ketakutan suatu individu yang mungkin muncul dalam menggunakan teknologi (Venkatesh et.al.,2003). Variabel ini diukur dengan 4 item pernyataan dengan skala Likert 1-6 (Abdulwahab, 2010).

h. Kondisi Pendukung yaitu adanya fasilitas organisasi dan teknis yang mensupport aktivitas user. Variabel ini diukur dengan 4 item pernyataan, dengan skala Likert 1-6 (Venkatesh, et.al.,2003)

\section{Uji Kualitas Data}

Untuk mengetahui validasi item pernyataan dalam penelitian ini dilakukan dengan discrimination validity dengan menggunakan PLS. Selain itu juga dilakukan dengan.melihat nilai AVE (Average Variance Extracted). Nilai AVE harus lebih besar dari 0.5 menurut Fornel dan Larcker (dalam Ghozali, $2006: 25$ ). 
Pengujian reliabilitas setiap variabel dilakukan dengan Composit Reliability. Data yang diperoleh akan dapat dikatakan reliable apabila nilai Composit reliability lebih besar atau sama dengan 0.70 .

\section{Metode Analisis Data}

Pada penelitian ini digunakan dua pengolahan data yaitu analisa yang bersifat deskriptif dan analisa yang bersifat analitik.

\section{Pengujian Hipotesis}

Berikut ini persamaan yang merefleksikan pengujian hipotesis yang ditunjukkan untuk menguji hubungan penerimaan user terhadap ERP dengan sikap dalam menggunakan sistem, ekspektasi kinerja, ekspektasi usaha, pengaruh sosial, kondisi pendukung, intervensi manajerial, dan Anxiety.

Persamaan untuk mengujihipotesis adalah sebagai berikut:

$$
\begin{aligned}
& \text { SDMS }=\alpha+\beta_{1} E K+\beta_{2} E U+\beta_{3} P S+\beta_{4} I M+\beta_{5} C A X+\varepsilon_{1} \\
& \text { SA }=\alpha+\beta_{6}+\beta_{7}+\varepsilon_{2}
\end{aligned}
$$

Keterangan :

EK : Ekspektasi Kinerja, EU: Ekspektasi Usaha, PS: Pengaruh Sosial IM : Intervensi Manajerial, AX: Anxiety, KP : Kondisi Pendukung SDMS: Sikap Dalam Menggunakan Sistem, SA: Symbolic Adoption $\alpha:$ Konstanta, $\beta$ : Koefisien regresi, $\varepsilon$ : Error

\section{Analisis dan Pembahasan}

\section{Uji Validitas}

Pengujian validitas yang digunakan dalam penelitian ini dengan menggunakan convergent validity dan discriminant validity. Dalam penelitian ini tidak terdapat item yang tidak valid, sehingga secara otomatis tidak ada indikator yang harus di drop dari model penelitian yang telah dibangun. 
Tabel 1AVE dan Akar AVE

\begin{tabular}{|c|c|c|}
\hline Construct & A & .. AkE AVE \\
\hline EK & 0.614 & 0.783581521 \\
\hline EU & 0.716 & 0.846167832 \\
\hline PS & 0.582 & 0.762889244 \\
\hline IM & 0.563 & 0.750333259 \\
\hline AX & 0.747 & 0.864291617 \\
\hline KP & 0.608 & 0.779743547 \\
\hline SDMS & 0.689 & 0.830060238 \\
\hline SA & 0.548 & 0.74027022 \\
\hline
\end{tabular}

Sedangkan korelasi antar variable adalah sebagai berikut:

Tabel 2 : Correlation of the latent variables

\begin{tabular}{|l|l|l|l|l|l|l|l|l|}
\hline & EK & EU & PS & IM & AX & KP .... & SDMS & SA \\
\hline EK $\therefore$ & 1.000 & & & & & & & \\
\hline EU & 0.452 & 1.000 & & & & & & \\
\hline \hline PS & 0.783 & 0.474 & 1.000 & & & & & \\
\hline $\mathrm{IM}$ & 0.411 & 0.450 & 0.354 & 1.000 & & & & \\
\hline AX $\therefore$ & -0.072 & -0.270 & 0.041 & 0.120 & 1.000 & & & \\
\hline $\mathrm{KP}$ & 0.678 & 0.482 & 0.458 & 0.545 & -0.280 & 1.000 & & \\
\hline SDMS. & 0.745 & 0.635 & 0.585 & 0.477 & -0.330 & 0.745 & 1.000 & \\
\hline SA & 0.499 & 0.595 & 0.362 & 0.547 & -0.402 & 0.606 & 0.813 & 1.000 \\
\hline
\end{tabular}

Dari tabel di atas dapat disimpulkan bahwa semua variabel memiliki discriminant validity yang tinggi.

\section{Uji Reliabilitas}

Untuk mengukur reliabilitas pada data konstruk dapat menggunakan composite reliability. Konstruk memiliki reliabilitas 
yang baik jika composite reliability-nya diatas 0.70 . Berikut hasil perhitungan konstruk menggunakan PLS:

Tabel 3 : Composite Reliability

\begin{tabular}{|c|c|}
\hline Construct & Compòsite Reliability \\
\hline EK & 0.861 \\
\hline EU & 0.937 \\
\hline PS & 0.892 \\
\hline IM & 0.859 \\
\hline AX & 0.921 \\
\hline KP & 0.860 \\
\hline SDMS & 0.898 \\
\hline SA & 0.756 \\
\hline
\end{tabular}

Dari tabel di atas dapat disimpulkan bahwa setiap variabel dapat dikatakan reliable, karena hasil composite reliability untuk masingmasing variabel di atas 0.70 .

\section{Merilai Inner Model atau Struktural Hasil Penelitian}

Menilai inner model digunakan untuk mengevaluasi hubungan konstruk laten atau variabel yang telah dihipotesiskan dalam penelitian ini yaitu hal-hal yang mempengaruhi penerimaan user dalam implementasi sistem SAP. Berikut adalah perhitungan inner model dari data yang diperoleh dengan menggunakan PLS :

Tabel 4: Result for inner weight

\begin{tabular}{|l|c|c|c|c|}
\hline & $\begin{array}{c}\text { Original sample } \\
\text { estimate }\end{array}$ & $\begin{array}{c}\text { Mean of } \\
\text { subsamples }\end{array}$ & $\begin{array}{c}\text { Standard } \\
\text { deviation }\end{array}$ & T-Statistic \\
\hline EK $\rightarrow$ SDMS & 0.566 & 0.554 & 0.152 & 3.721 \\
\hline EU $>$ SDMS & 0.251 & 0.264 & 0.113 & 2.213 \\
\hline PS $>$ SDMS & -0.027 & -0.011 & 0.166 & 0.164 \\
\hline IM $>$ SDMS & 0.170 & 0.168 & 0.127 & 1.334 \\
\hline AX $>$ SDMS & -0.241 & -0.216 & 0.095 & 2.540 \\
\hline
\end{tabular}




\begin{tabular}{|l|l|l|l|l|}
\hline KP -> SA & 0.000 & 0.039 & 0.126 & 0.004 \\
\hline SDMS -> SA & 0.813 & 0.790 & 0.116 & 6.976 \\
\hline
\end{tabular}

Gambar model hasil penelitian dapat dilihat pada gambar berikut ini:

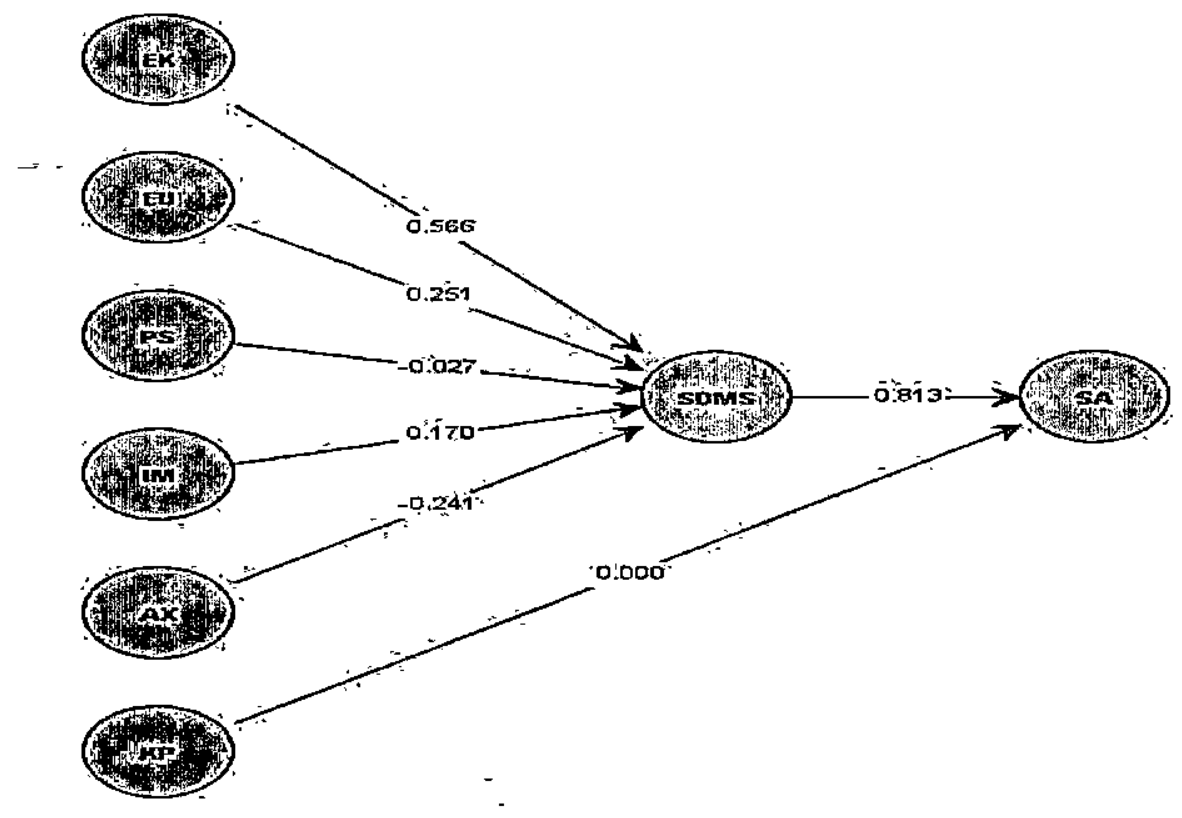

\section{Pengujian Hipotesis}

a. Ekspektasi Kinerja (EK) berpengaruh positif terhadap Sikap

\section{Dalam Menggunakan Sistem (SDMS)}

Dari data yang diolah diketahui bahwa ekspektasi kinerja memiliki nilai original sample estimate sebesar 0.566 yang menunjukkan bahwa hubungan antara ekspektasi kinerja dengan sikap dalam menggunakan sistem bernilai positif, sedangkan untuk $\mathrm{T}$ statistik sebesar 3.721 . Dengan hasil tersebut maka hipotesis satu (H1) yang menyatakan bahwa ekspektasi kinerja (EK) berpengaruh positif dengan sikap dalam - menggunakan sistem (SDMS) didukung oleh data yang ada. 
Hal ini berarti bahwa besarnya manfaat yang dirasakan dan harapan pengguna SAP yang akan meningkatkan performasi kinerja mereka, membentuk sikap mereka terhadap SAP, sikap positif yang merupakan pendapat user tentang SAP, akhirnya mempengaruhi penerimaan mereka terhadap sistem. Hasil penelitian ini sejalan dengan teori penerimaan secara umum dimana faktor manfaat adalah hal yang mendorong sikap penerimaan (Nah et.al, 2004) .

b. Ekspektasi Usaha (EU) berpengaruh positif terhadap Sikap Dalam Menggunakan Sistem (SDMS)

Ekspektasi usaha (EU) memiliki nilai original sample estimate sebesar 0.251 menunjukkan bahwa hubungan antara ekspektasi usaha (EU) dengan sikap dalam menggunakan sistem (SDMS) bernilai positif, sedangkan untuk $\mathrm{T}$ statistik sebesar 2.213. Dengan menggunakan signifikansi 0.05 ( $\mathrm{T}$ statistik $>\mathrm{T}$ table 1.64) dan hasil perhitungan inner weight yang menunjukkan arah hubungan, maka hipotesis dua $(\mathrm{H} 2)$ yang menyatakan bahwa ekspektasi usaha (EU) berpengaruh positif dengan sikap dalam menggunakan sistem (SDMS) didukung oleh data yang ada.

Dari hasil pengolahan data yang dilakukan dapat diinterpretasikan bahwa- ekspektasi usaha (EU) berpengaruh positif terhadap sikap dalam menggunakan sistem (SDMS). Nilai positif pada original sample estimate diartikan bahwa sistem aplikasi SAP merupakan hal yang mudah digunakan, user percaya bahwa menggunakan sistem aplikasi SAP mampu memberikan peningkatan performansi user dalam bekerja. Hal ini membentuk suatu persepsi pada diri user bahwa sistem aplikasi SAP bermanfaat dalam menyelesaikan suatu pekerjaan. Selain itu user merasakan bahwa dengan menggunakan sistem aplikasi SAP mampu memberikan efektifitas, akurasi dan efisiensi dalam melakukan sebuah 1814 
pekerjaan. Hasil penelitian ini sejalan dengan penelitian yang telah dilakukan oleh Marchewka (2007).

\section{c. Pengaruh Sosial (PS) berpengaruh positif terhadap Sikap Dalam Menggunakan Sistem (SDMS)}

Pengaruh sosial memiliki nilai original sample estimate sebesar -0.027 yang menunjukkan bahwa hubungan antara pengaruh sosial (PS) dengan sikap dalam menggunakan sistem bernilai negatif, sedangkan untuk $T$ statistik sebesar 0.164 . Dengan menggunakan signifikansi 0.05 dan hasil perhitungan inner weight yang menunjukkan arah hubungan maka hipotesis tiga (H3) yang menyatakan bahwa pengaruh sosial (PS) berhubungan positif dengan sikap dalam menggunakan sistem (SDMS) tidak didukung oleh data yang ada.

Dari hasil pengujian tersebut maka dapat diinterpretasikan bahwa dalam penelitian ini pengaruh sosial (PS) tidak terbukti berpengaruh positif terhadap sikap dalam menggunakan sistem (SDMS). Nilai negatif pada original sample estimate diartikan bahwa lingkungan yang ada disekitar user tidak mempengaruhi pada keputusan user untuk menggunakan sistem aplikasi SAP atau tidak menggunakan. Hal ini juga dikarenakan adanya pengaruh mandat dari manajemen puncak yang mau tidak mau para karyawan/user harus mengikuti keputusan yang telah diambil oleh manajemen puncak mengenai penggunaan SAP. Hasil penelitian ini tidak mendukung penelitian sebelumnya yang dilakukan oleh Venkatesh, et.al (2003) yang menyatakan pengaruh sosial sebagai faktor yang mempengaruhi penerimaan sistem.

d. Intervensi Manajerial (IM) berpengaruh positif terhadap Sikap Dalam Menggunakan Sistem (SDMS)

Dari hasil pengolahan data- didapatkan bahwa intervensi manajerial memiliki nilai original sample estimate sebesar 0.170 
menunjukkan bahwa hubungan antara intervensi manajerial dengan sikap dalam menggunanakan sistem bernilai positif, sedangkan untuk $\mathrm{T}$ statistik sebesar 1.334. Dengan demikian maka hipotesis empat (H4) yang menyatakan bahwa intervensi manajerial (IM) berhubungan positif dengan sikap dalam menggunakan sistem (SDMS) tidak didukung oleh data yang ada.

- Dari hasil pengolahan data yang dilakukan dapat diinterpretasikan bahwa intervensi manajerial (IM) tidak terbukti memiliki pengaruh positif dengan variabel sikap dalam menggunakan sistem (SDMS). Hal ini dikarenakan minimnya tindakan dari pihak manajemen puncak dan komitmen dalam mendukung keberhasilan implementasi sistem aplikasi SAP ini. User tidak merasakan adanya dukungan dari manajemen puncak. Untuk meningkatkan kualitas dan keberhasilan dalam implementasi sistem aplikasi SAP ini, sebaiknya pihak manajemen puncak memberikan suatu motivasi pada user. Pemberian motivasi ini bisa dilakukan dengan berbagai cara, diantaranya adalah dengan memberikan insentif khusus bagi user yang berprestasi dalam proses penggunaan SAP. Memberikan dorongan kepada user untuk menggali ilmu dalam bidang SAP dengan memfasilitasi pendidikan mereka. Hasil penelitian ini tidak mendukung penelitian sebelumnya yang dilakukan oleh' Komara, Acep (2006) yang menjelaskan bahwa dukungan top manager (manager invention) mempengaruhi kinerja sistem informasi akuntansi.

\section{e. Anxiety (AX) berpengaruh negatif terhadap Sikap Dalam}

\section{Menggunakan Sistem (SDMS)}

Dari data yang diolah didapatkan bahwa pengaruh sosial memiliki nilai original sample estimate sebesar -0.241 menunjukkan bahwa hubungan antara Anxiety $(A X)$ dengan sikap dalam menggunakan sistem 1816 
(SDMS) bernilai negatif, sedangkan untuk T statistik sebesar 2.540 . Dengan demikian maka hipotesis lima (H5) yang menyatakan bahwa anxiety $(A X)$ berhubungan negatif dengan sikap dalam menggunakan sistem (SDMS) didukung oleh data yang ada.

Dari hasil pengujian dapat diinterpretasikan bahwa terdapat tingkat kecemasan yang kecil dalam diri user untuk menggunakan sistem aplikasi SAP sehingga meningkatkan rasa percaya diri dan keyakinan pada diri user bahwa mereka mampu dan bisa menggunakan sistem aplikasi SAP. Hasil tersebut sekaligus mendukung penelitian Abdulwahab (2010) yang menjelaskan bahwa Anxiety tidak memiliki hubungan yang positif terhadap sikap dalam menggunakan sistem (behavior intention). Marchewka (2007) dalam penelitiannya menghasilkan kesimpulan bahwa Anxiety memiliki hubungan yang tidak - positif (negative) dengan sikap dalam menggunakan sistem (SDMS).

\section{f. Kondisi Pendukung (KP) berpengaruh positif terhadap Symbolic Adoption (SA)}

Dari data yang diolah didapatkan bahwa kondisi pendukung memiliki nilai original sample estimate sebesar 0.000 menunjukkan bahwa hubungan antara kondisi pendukung (KP) dengan symbolic adoption (SA) bernilai positif, sedangkan untuk T statistik sebesar 0.004 . Dengan demikian maka hipotesis enam (H6) yang menyatakan bahwa kondisi pendukung (KP) berhubungan positif dengan symbolic adoption (SA) tidak didukung oleh data yang ada.

Dari hasil pengolahan data yang dilakukan dapat diinterpretasikan bahwa kondisi lingkungan perusahaan tidak merata secara keseluruhan dalam menciptakan kondisi yang mendukung terciptanya keberhasilan implementasi sistem aplikasi SAP ini. Hasil tersebut tidak mendukung 
penelitian yang dilakukan oleh Venkatesh et.al (2003), yang menyatakan bahwa kondisi pendukung mempengaruhi penerimaan sistem.

g. Sikap Dalam Menggunakan Sistem Berpengaruh Positif terhadap Symbolic Adoption (SA)

Dari data yang diolah didapatkan bahwa sikap dalam menggunakan sistem memiliki nilai original sample estimate sebesar 0.813 menunjukkan bahwa hubungan antara sikap dalam menggunakan sistem (SDMS) dengan symbolic adoption (SA) bernilai positif, sedangkan untuk $\mathrm{T}$ statistik sebesar 2.527. Dengan demikian maka hipotesis tujuh (H7) yang menyatakan bahwa sikap dalam menggunakan sistem berhubungan positif dengan symbolic adoption (SA) didukung oleh data yang ada.

Dari hasil pengolahan data yang dilakukan dapat diinterpretasikan bahwa sikap dalam menggunakan sistem memiliki hubungan positif terhadap symbolic adoption (SA). Artinya bahwa. Sistem SAP telah diterima oleh staff pengguna SAP. Universitas Islam Indonesia telah berhasil membentuk sikap positif karyawan terhadap penggunaan sistem aplikasi SAP. Hasil penelitian ini mendukung penelitian sebelumnya, bahwa sikap (attitude) seseorang merupakan faktor yang berperan penting dalam kaitannya memberikan keputusan untuk menerima sistem aplikasi SAP ( Nah, Tan, dan Teh, 2004).

\section{Kesimpulan dan Saran}

1. Kesimpulan

Berdasarkan hasil penelitian, peneliti dapat menyimpulkan bahwa : 
a. Ekspektasi Kinerja dan Ekspektasi usaha terbukti berpengaruh positif terhadap Sikap Dalam Menggunakan Sistem, sedangkan Pengaruh Sosial dan Intervensi Manajerial tidak terbukti berpengaruh positif terhadap Sikap Dalam Menggunakan Sistem.

b. Anxiety terbukti berpengaruh negatif terhadap Sikap Dalam Menggunakan Sistem.

c. Kondisi Pendukung tidak terbukti berpengaruh positif terhadap Symbolic Adoption.

d. Sikap Dalam Menggunakan Sistem terbukti berpengaruh positif terhadap Symbolic Adoption.

\section{Implikasi Penelitian}

Hasil dari penelitian itu diharapkan dapat memberikan referensi bagi jajaran manajemen Universitas Islam Indonesia untuk mengetahui faktor-faktor penting apa saja yang mempengaruhi penerimaan user terhadap sistem dalam implementasi SAP.-Faktor-faktor yang perlu diperhatikan adalah Ekspektasi kinerja, ekspektasi usaha, pengaruh sosial, intervensi manajerial, anxiety, dan kondisi pendukung karena dari setiap unsur tersebut memiliki peranan yang sangat berpotensi untuk meningkatkan kualitas dan kesuksesan dalam rangka pengimplementasian sistem aplikasi SAP.

\section{Keterbatasan Penelitian}

Penelitian ini tidak terlepas dari keterbatasan, yaitu keterbatasan penelitian ini adalah objek penelitian yang hanya terpusat pada Universitas Islam Indonesia sehingga hasilnya belum bisa digeneralisasikan. 


\section{Saran}

Saran untuk penelitian yang akan datang yaitu penelitian berikutnya seharusnya dapat lebih memperluas objek penelitan dan sampel supaya bisa diperoleh kesimpulan dan informasi yang lebih luas dengan didasarkan pada karakteristik tertentu di suatu wilayah. 


\section{DAFTAR PUSTAKA}

Abdulwahab, L \& Z.M. Dahalin, 2010, “ $a$ Conceptual Model of Unified Theory of Acceptance and Usage of Technology (UTAUT) Modification with Management Effectiveness and Program Effectiveness in Context of Telecentre". African Scientist Vol.11, No.4

Ghozali, Imam, 2006, "Structural Equation Modeling Metode Alternatif dengan Partial Least Square", Semarang: Universitas Diponegoro.

Komara, Acep, 2006, "Analisis Faktor-faktor yang Mempengaruhi Kinerja Sistem Informasi Akuntansi".Solo : Simposium Nasional Akuntansi VIII

Marchewka Jack.T \& Kurt Kostiwa, 2010, "An Application of the UTAUT Model for Understanding Student Perceptions Using Course Management Software". communications of the IIMA

Marantika, Budiarningsih, 2010, "Model Penerimaan User Dalam Implementasi Sistem SAP Dengan Menggunakan Model UTAUT". Studi kasus pada PT Pertamina EP UBEP Jambi, Skripsi S-1, Fakultas Ekonomi, Universitas Islam Indonesia, Yogyakarta

Masbukhin, 2009, Pengantar SAP, Retrieved -November 22. www.ilmukomputer.com

Nah F.F.H., Tan X, dan Teh S.H., 2004, “An Empirical Investigation on End-User's Acceptance of Enterprise Systems". Information Resources Management Journal, No. 3.

Sedana, I Gusti Nyoman \& St. Wisnu Wijaya, 2010, "UTAUT Model for Understanding Learning Management System".Universitas Sanata Dharma, Yogyakarta.

Venkatesh, V., Morris M.G, Davis G.B, \& Davis, F.D, 2003, "User Acceptance of Information Technology: Toward a Unified View", MIS Quarterly Vol.27, No.3

Winarno, Wing Wahyu, 2004, "Sistem Informasi Manajemen", Yogyakarta: LPP AMP YKPN 
Darmawan Hambara Kusuma \& Abriyani Puspaningsih, Model Penerimaan User.... 